\title{
SECRETARY'S REPORT FOR 1933
}

Historical.

As this year marks the completion of twenty-five years of work of the Society, it is only fitting that some reference should be made to this fact.

The Society was organized in 1908 in Montreal and the first annual meeting was held in Ottawa, March 11th, 1909. There is no reference in the Records to a meeting in 1910, although it is possible that a meeting was held. (The Secretary would like to have this verified). Actually then, it is our twenty-fifth meeting, but, if one was held in 1910, it becomes the twenty. sixth annual meeting.*

As the Society has grown greatly in numbers since this first meeting twenty-six years ago, and especially for the younger members of the Society, it has been thought appropriate to insert here the minutes of the inauguration meetings.

\author{
"Committee Room, \\ Board of Trade Chambers, \\ Montreal, P.Q., \\ March 12, 1908.
}

"A meeting of professional foresters was held in the Committee Room of the Board of Trade Chambers at Montreal on the evening of Thursday, March 12th, 1908. The meeting convened at 10 p.m., immediately after a lecture delivered by Prof. F. Roth, and was attended by the following; Dr. B. E. Fernow, Dean of the Faculty of Forestry, University of Toronto, Toronto, Mr. Thos. Southworth of Toronto, Director of Colonization for Ontario, Mr. A. Knechtel, B.S., F.E., of Ottawa, Inspector of Forest Reserves for the Dominion of Canada, Mr. E. J. Zavitz, B.A., M.S.F., of Guelph, Ont., Forester to the Ontario Department of Agriculture, Mr. A. H. D. Ross, M.A., M.F., of Toronto, Lecturer in forestry, University of Toronto, Mr. Ellwood Wilson, C.E., of Grandmere, P.Q., Forester to the Laurentide Pulp and Paper Co., Mr. G. C. Piche, of Montreal, P.Q., Forester attached to the Department of Lands and Forests of Quebec, Marshall C. Small, of the Laurentide Pulp and Paper Company, Grandmere, P.Q., F. W. H. Jacombe, M.A., M.F., Technical Assistant, Forestry Branch, Department of the Interior, Ottawa, Ont.

"At the request of the meeting Dr. Fernow took the chair and explained the object of the meeting, namely, to form an organization of professional foresters in Canada for the discussion of technical subjects relative to the theory and practice of forestry, and for social purposes.

*Mr. Jacombe, who was secretary at that time, informs me that no meeting was held in 1910. [Sec.] 
"Mr. Jacombe also spoke briefly to the same effect, suggesting that at first the social feature be kept especially prominent, and that the discussion of technical subjects be left until a somewhat later date when forestry in Canada should have reached a more advanced stage.

"After a number of those present had spoken heartily endorsing the proposal, it was

"Moved by Mr. Wilson, seconded by Mr. Knechtel that an organization be formed of the character proposed in the remarks of the chairman and others and that a committee be appointed to draft a constitution. The motion was carried unanimously.

"Further informal discussion ensued as to the name and scope of the organization and other points.

"It was decided to meet again at a dinner to be held on Friday evening,

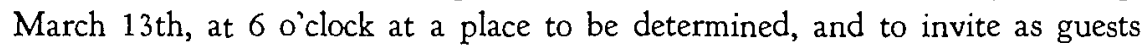
of the evening Messrs. O. W. Price, F. Roth and A. E. Stirling.

"The chairman named as convener of the committee to draft the constitution and attend to the arrangements for the dinner, Mr. Jacombe, who chose as his associates Messrs. Wilson and Piche.

"The meeting then adjourned.

$$
\begin{aligned}
& \text { "Place Viger Hotel, } \\
& \text { Montreal, P.Q., } \\
& \text { March 13th, } 1908 .
\end{aligned}
$$

"In accordance with the resolution of those present at the informal meeting of foresters in the Board of Trade Committee Room on Thursday evening, March 12th, a meeting of those interested in the formation of a society of professional Canadian foresters, was held this evening at six o'clock at the place above named.

"Messrs. Overton, W. Price, Filibert Roth and Hugh P. Baker were present as guests. The others present were Dr. B. E. Fernow and Messrs. E. Stewart, Thos. Southworth, Abraham Knechtel, E. J. Zavitz, A. H. D. Ross, G. C. Piche, Ellwood Wilson, W. C. J. Hall, Reginald R. Bradley, Marshall C. Small and F. W. H. Jacombe.

"After dinner the committee appointed on Thursday evening to prepare a constitution, presented their report, Mr. Wilson in the chair. The report was considered clause by clause and, after amendment, adopted."

"Election of Officers.

The election of officers was then taken up. For president the following were nominated:-

Mr. R. H. Campbell, by Mr. Knechtel and Mr. Piche. 
Mr. E. Wilson, by Mr. Southworth and Dr. Fernow.

Dr. Fernow, by Mr. A. H. D. Ross and Mr. Bradley.

"Mr. Wilson having withdrawn, a ballot was taken which resulted in favour of Dr. Fernow.

"For vice-president Mr. R. H. Campbell was nominated by Messrs. Knechtel and Jacombe and declared elected by acclamation.

"For secretary-treasurer Mr. Jacombe was nominated by Messrs. Ross and Zavitz and declared elected by acclamation.

"As members of the executive Mr. Piche was nominated by Messrs. Hall and Jacombe, and Mr. R. R. Bradley by Messrs. Zavitz and Jacombe.

"There being no other nominations these gentlemen were declared elected.

"The meeting then adjourned.

B. E. Fernow,

F. W. H. JACOMBE,

President.

Secretary-Treasurer."

In 1915 the Society applied for letters patent from the Provincial Secretary of Ontario, and this document, with its brave display of illuminated letters, coloured ribbon and sealing wax, was granted on the ninth of September of that year and bears the names of:

\author{
Bernhard Eduard Fernow, \\ Robert Henry Campbell, \\ Clyde Leavitt, \\ Ellwood Wilson, \\ Gustav Clodomir Piche, \\ Norman McKenzie Ross, \\ Harvey Reginald MacMillan.
}

Canadian Forestry Association Controversy.

During the year the Executive and several members of the Society have taken an active part in the Canadian Forestry Association controversy. It was felt that, as this matter so seriously effects forestry progress in Canada, the Society should take a definite stand and lend its weight in an attempt to bring the Association back to the work which it was originally intended to do. Consequently, your Executive sponsored the issuing of the Dallyn report and the statement, to the Board of Directors of the Association, prepared by E. H. Finlayson. Copies of both of these have been distributed to all members. One of the important items of business at the annual meeting should be a discussion of these matters and what stand the Society should take regarding them. 
Membership.

The membership of the Society has dropped slightly during the year, owing to resignations and deaths. The total membership as shown below now stands at 366 :

$\begin{array}{lc}\text { Senior } & 198 \\ \text { Junior } & 149 \\ \text { Affiliate } & 3 \\ \text { Honorary } & 6\end{array}$

I regret to announce that during the year three members have been taken from our midst by death, namely, Major General Lord Lovat, who has been an honorary member of this Society for several years and who passed away on February 18th, 1933; Eric G. Fowler, one of the younger members of the Society, who passed away on April 19th, 1933, and Professor W. N. Millar, who died on June 29th, 1933. Besides these three members reference should also be made to a staunch friend of forestry in Canada, namely, Mr. Frank J. D. Barnjum, who died on February 20th, 1933, and Major R. Y. Stuart, Chief Forester of the United States Forest Service, who passed away on October 23rd, 1933.

A full obituary notice of each of these men will be found in the December number of the Chronicle.

\section{Chronicle.}

The four numbers of the Chronicle have been maintained this year, but the last two have been rather slow in being published, due to the fact that funds were low owing to the tardiness of members in paying their dues and also because sufficient material was not on hand to fill the number. The editor still suffers from lack of co-operation on the part of members in this regard and it is felt that the senior members, particularly those who are in charge of different forestry projects throughout the country, could assist materially in this matter by seeing that their assistants and subordinates supply material for the Chronicle. It often happens, too, that technical articles are written by foresters and are published first in trade and other journals throughout the country and are not submitted for publication in the official chronicle of the Society.

Respectfully submitted,

Arthur Herbert Richardson. 